\title{
H5N8 AVIAN INFLUENZA VIRUS IN ASWAN GOVERNORATE
}

\author{
A.I. AHMED ${ }^{1}$; N. OSMAN ${ }^{1}$; SOAD A. NASEF ${ }^{2}$ and S.G. BAKRY ${ }^{3}$ \\ ${ }^{1}$ Department of Poultry Diseases, Faculty of Veterinary Medicine, South Valley University, \\ 83523 Qena, Egypt \\ ${ }^{2}$ Central Laboratory for Veterinary Quality Control on Poultry Production (CLQP), Cairo, Egypt; \\ ${ }^{3}$ Animal Health Research Institute, Aswan Laboratory, Aswan, Egypt
}

Received: 26 February 2019; Accepted: 11 March 2019

\begin{abstract}
Egypt has experienced outbreaks of avian influenza (AI) since 2006. Tracheal and cloacal swabs were collected from three hundred and thirty four domestic poultry (one hundred and sixty eight ducks, one hundred and fifty six chickens, ten geese) from 50 houses from different parts in Aswan governorate. Tracheal and cloacal swabs were examined for the presence of avian influenza virus by real-time RT-PCR. H5N8 genome was detected in 26 out of 334 examined birds, giving a ratio of $7.7 \%$. The species wise distribution of RT-PCR results was $8.3 \%$, $7.6 \%, 0.0 \%$ for ducks, chickens and geese respectively. Clinical signs of avian influenza were appeared on most of positive cases which have been examined for AI in the form of: significant mortality may be as high as $100 \%$ within 3-4 days after infection, respiratory signs such as (cough, sneezing and respiratory discharge), swelling and cyanosis in comb and wattles and some birds that survive longer exhibit nervous signs. The main clinical feature in ducks was nervous signs (torticollis, other unusual positions of the head and complete reluctance to move) with high mortality rate from $50 \%$ up to $100 \%$.
\end{abstract}

In conclusion, the predominance of H5 infection indicates a need for continuous monitoring of AIV among avian species and the awareness against public health risk.

Key words: Avian influenza virus, H5N8, backyard ducks, chicken, geese.

\section{INTRODUCTION}

Avian influenza (AI) is a highly contagious disease and the global spread in bird populations represents a major problem. Both, highly pathogenic avian influenza (HPAI) H5N1 and low pathogenic avian influenza (LPAI) H9N2 viruses have been endemic in Egyptian poultry flocks since 2006 and 2011, respectively (Saad et al., 2007; Arafa et al., 2012). Recently, H5N8 HPAI virus of clade 2.3.4.4 has been introduced to Egypt through migratory birds in 2016 (Kandeil et al., 2017; Selim et al., 2017). Later, the same lineage of virus was isolated from domestic ducks in 2017 (Yehia et al., 2018).

Aquatic birds, including ducks, are generally considered to be the natural reservoir of LPAI viruses. HPAI viruses of certain $\mathrm{H} 5$ and $\mathrm{H} 7$ strains are thought to be derived from LPAI viruses of wild bird origin (Webster et al., 1992; Olsen et al., 2006).

Corresponding author: Dr. A.I. AHMED

E-mail address: Ibrahim.ahmed25@yahoo.com

Present address: Department of Poultry Diseases, Faculty of Veterinary Medicine, South Valley University, 83523 Qena, Egypt
The geographical location of Egypt makes it an important migration spot for migratory birds crossing Europe, Asia and Africa. Spread of AI virus from wild to domestic populations occurred both within and between regions, while viral flow from domestic to wild birds was restricted within a geographic region (Bahl et al., 2016). The transmission of AI virus from migratory birds to domestic poultry can represent an additional public health threat in Egypt.

H5N8 subtype clade 2.3.4.4 was first detected in domestic poultry in China in 2010. By 2014, H5N8 HPAI viruses had caused a series of outbreaks among domestic ducks, chickens, geese and wild birds in South Korea, and outbreaks followed in Japan, China, Europe and North America (Lee et al., 2015, 2016). As of March 2017, the virus had spread across most European countries, the Middle East and Africa (World Organisation for Animal Health [OIE], 2018).

The cross-reactivity between the classical 2.2.1 and the variant 2.2.1.1 $\mathrm{H} 5 \mathrm{~N} 1$ viruses was low and both clusters showed significant antigenic differences by using cross haemagglutination inhibition (HI) assay 
(Ibrahim et al., 2013). Importantly, the protective efficacy of the commercial inactivated vaccines used in Egypt against the circulating variant 2.2.1.1 viruses was impaired (Abdelwhab et al., 2011). This can be explained by the mutations in major antigenic sites as previously demonstrated (Ibrahim et al., 2015). No cross-reactivity was observed between HPAI H5N1 strains from different clades and two HPAI H5N8 viruses isolated in 2014 from the Netherlands and Korea, although H5N1 vaccines tested in these studies conferred significant crossprotection against HPAI H5N8 virus challenge (De Vries et al., 2015; Park et al., 2016).

The clinical signs observed in ducks infected with HPAI H5N8 virus include lethargy, nasal discharge and neuronal signs such as torticollis and other unusual positions of the head with a remarkable increase in mortality rate from $50 \%$ up to $100 \%$.

The aim of this study was to study the prevalence of HPAI (H5N8) in poultry among different locations in Aswan governorate.

\section{MATERIALS AND METHOD}

Tracheal swabs were collected from domestic birds from backyards in Aswan Governorate. The swabs were pooled and the maximum size of pool consist of five samples, while suspected samples were tested without pooling.

For taking a swab sample: Insert the swab into the cloaca or trachea, swabbing the area thoroughly. Place the swab into 1-2 mL of viral transport media and swirl vigorously to dispel the contents of the swab into the media. Lift the swab out of the media; press the swab firmly against the side of the tube to remove any remaining liquid from the swab. Discard the swab into a disinfectant solution. Transport samples immediately to the laboratory on wet ice for RT-PCR examination.

Firstly, the viral RNA was extracted from the collected swab samples by using QIAamp Viral RNA Mini Kit (QIAGEN) catalogue No. 52904, and the protocol was conducted according to the kit instructions. Then, one step RT-PCR was carried out using QuantiTect ${ }^{\circledR}$ probe RT-PCR kit catalogue No. 204443

Oligonucleotide Primers and probes. Primers and probes used were supplied from Metabion® (Germany) are listed in table (1).

\begin{tabular}{|c|c|c|c|}
\hline Virus & Gene & $\begin{array}{l}\text { Primer/ probe sequence } \\
\qquad 5^{\prime}-3^{\prime}\end{array}$ & Ref \\
\hline \multirow[t]{27}{*}{ AI } & \multirow[t]{7}{*}{ H5 } & H5LH1 & \multirow[t]{7}{*}{ Löndt et al., 2008} \\
\hline & & ACATATGACTAC CCACARTATTCA G & \\
\hline & & H5RH1 & \\
\hline & & AGACCAGCT AYC ATGATTGC & \\
\hline & & H5PRO & \\
\hline & & [FAM]TCWACA GTGGCGAGT & \\
\hline & & TCCCTAGCA[TAMRA] & \\
\hline & \multirow[t]{7}{*}{ H9 } & H9F & \multirow[t]{7}{*}{ Ben Shabat et al., 2010} \\
\hline & & GGAAGAATTAATTATTATTGGTCGGTAC & \\
\hline & & H9R & \\
\hline & & GCCACCTTTTTCAGTCTGACATT & \\
\hline & & $\begin{array}{l}\text { H9 Probe } \\
\end{array}$ & \\
\hline & & [FAM]AACCAGGCCAGACATTGCGAGTAA & \\
\hline & & GATCC[TAMRA] & \\
\hline & \multirow[t]{6}{*}{ N1 } & N1 forward & \multirow[t]{6}{*}{ Li et al., 2013} \\
\hline & & TAYAACTCAAGGTTTGAGTCTGTYGCTTG & \\
\hline & & N1 reverse & \\
\hline & & ATGTTRTTCCTCCAACTCTTGATRGTGTC & \\
\hline & & N1 Probe & \\
\hline & & $\begin{array}{c}\text { FAM-TCAGCRAGTGCYTGCCATGATGGCA- } \\
\text { Tamra }\end{array}$ & \\
\hline & \multirow[t]{7}{*}{ N8 } & N8-1296F & \multirow[t]{7}{*}{ Hoffmann et al., 2016} \\
\hline & & TCC ATG YTT TTG GGT TGA RAT GAT & \\
\hline & & N8-1423R & \\
\hline & & GCT CCA TCR TGC CAY GAC CA & \\
\hline & & N8-1354 & \\
\hline & & FAM- TCH AGY AGC TCC ATT GTR ATG & \\
\hline & & TGT GGA GT-Tamra & \\
\hline
\end{tabular}


Cycling conditions of Primers and probes used are listed in table (2):

\begin{tabular}{ccccccc}
\hline Virus & $\begin{array}{c}\text { Reverse } \\
\text { Transcription }\end{array}$ & $\begin{array}{c}\text { Primary } \\
\text { Denaturation }\end{array}$ & $\begin{array}{c}\text { Secondary } \\
\text { Denaturation }\end{array}$ & Annealing & Extension & No. of cycles \\
\hline $\mathrm{H} 5$ & $50^{\circ} \mathrm{C}$ & $95^{\circ} \mathrm{C}$ & $94^{\circ} \mathrm{C}$ & $54^{\circ} \mathrm{C}$ & $72^{\circ} \mathrm{C}$ & 40 \\
& $30 \mathrm{~min}$. & $15 \mathrm{~min}$. & $15 \mathrm{sec}$. & $30 \mathrm{sec}$. & $10 \mathrm{sec}$. & \\
\hline $\mathrm{H} 9$ & $50^{\circ} \mathrm{C}$ & $95^{\circ} \mathrm{C}$ & $94^{\circ} \mathrm{C}$ & $60^{\circ} \mathrm{C}$ & 40 \\
& $30 \mathrm{~min}$. & $15 \mathrm{~min}$. & $15 \mathrm{sec}$. & $45 \mathrm{sec}$. & \\
\hline \multirow{2}{*}{$\mathrm{N} 1$} & $50^{\circ} \mathrm{C}$ & $95^{\circ} \mathrm{C}$ & $94^{\circ} \mathrm{C}$ & $55^{\circ} \mathrm{C}$ & $72^{\circ} \mathrm{C}$ \\
& $30 \mathrm{~min}$. & $15 \mathrm{~min}$. & $15 \mathrm{sec}$. & $30 \mathrm{sec}$. & $10 \mathrm{sec}$. \\
\hline \multirow{2}{*}{$\mathrm{N} 8$} & $50^{\circ} \mathrm{C}$ & $95^{\circ} \mathrm{C}$ & $94^{\circ} \mathrm{C}$ & $55^{\circ} \mathrm{C}$ & $72^{\circ} \mathrm{C}$ \\
& $30 \mathrm{~min}$. & $15 \mathrm{~min}$. & $15 \mathrm{sec}$. & $30 \mathrm{sec}$. & $10 \mathrm{sec}$. \\
\hline
\end{tabular}

\section{RESULTS}

Avian influenza virus (H5N8) subtype was detected by using real time PCR (RT-PCR)

A total 668 cloacal and tracheal swabs were collected from different localities in Aswan Governorate; samples were collected from household chicken, duck and geese.

These samples were examined for the presence of avian influenza virus (H5,H9 and N1,N8) subtypes by RT-PCR in Reference Laboratory for Veterinary Quality Control on Poultry Production in Giza.

H5N8 genome was detected in 26 out of 334 examined birds, giving a ratio of $7.7 \%$. The species wise distribution of RT-PCR results was $8.3 \%$, $7.6 \%, 0.0 \%$ for ducks, chickens and geese respectively (Table 3 ). These results appear within one hour and $49 \mathrm{~min}$ after starting the run. The samples are negative when they have no CT value, no crossing point and no amplification curve and the samples are positive when they have crossing point cycles Fig. (2), Fig. (3)

Clinical signs of avian influenza were appeared on most of positive cases which have been examined for $\mathrm{AI}$ in the form of: significant mortality may be as high as $100 \%$ within 3-4 days after infection, respiratory signs such as (cough and sneezing), swelling and cyanosis in comb and wattles, some birds that survive longer exhibit nervous signs characterized by prostration, complete reluctance to move, paralysis of wings, torticollis, opisthotonus and abnormal gait (Fig. 1).

Table 3: Prevalence of avian influenza among the examined chicken, duck and geese

\begin{tabular}{ccccccc}
\hline $\begin{array}{c}\text { Type of } \\
\text { birds }\end{array}$ & $\begin{array}{c}\text { No of } \\
\text { samples }\end{array}$ & $\begin{array}{c}\text { Total No of } \\
\text { samples }\end{array}$ & $\begin{array}{c}\text { Total No of } \\
\text { +ve samples }\end{array}$ & $\begin{array}{c}\text { No of +ve } \\
\text { samples }\end{array}$ & $\begin{array}{c}\% \text { of +ve } \\
\text { samples }\end{array}$ & $\begin{array}{c}\text { Total \% of } \\
\text { +ve samples }\end{array}$ \\
\hline Chicken & 156 & & 12 & $7.6 \%$ & \\
Duck & 168 & 334 & 26 & 14 & $8.3 \%$ & $7.7 \%$ \\
Geese & 10 & & 0 & $0.0 \%$ & \\
\hline
\end{tabular}


Figure (1): Clinical signs appear in chickens and ducks due to AIV infection Nervous sigs, ruffled feather \& Swelling and cyanosis of comb and wattles in chickens
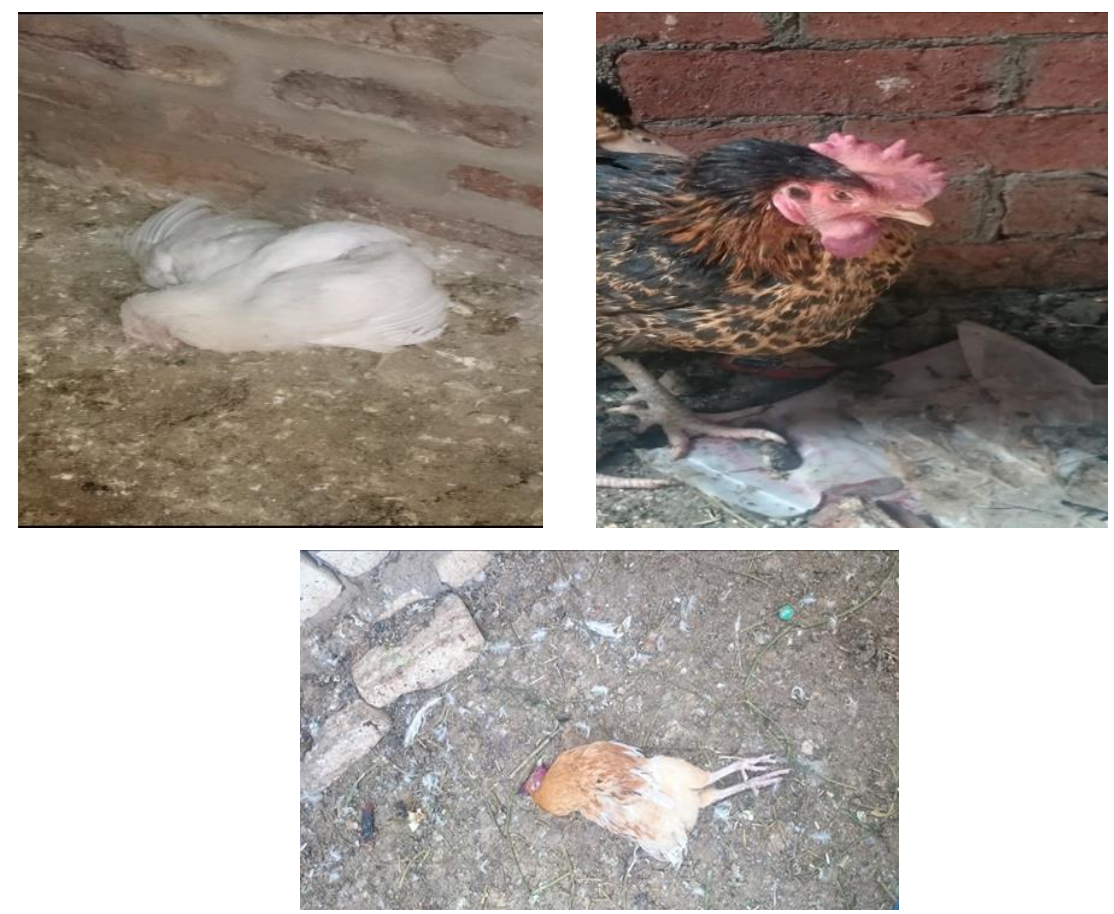

Nervous signs in duck and chicken (unusual position of the head)
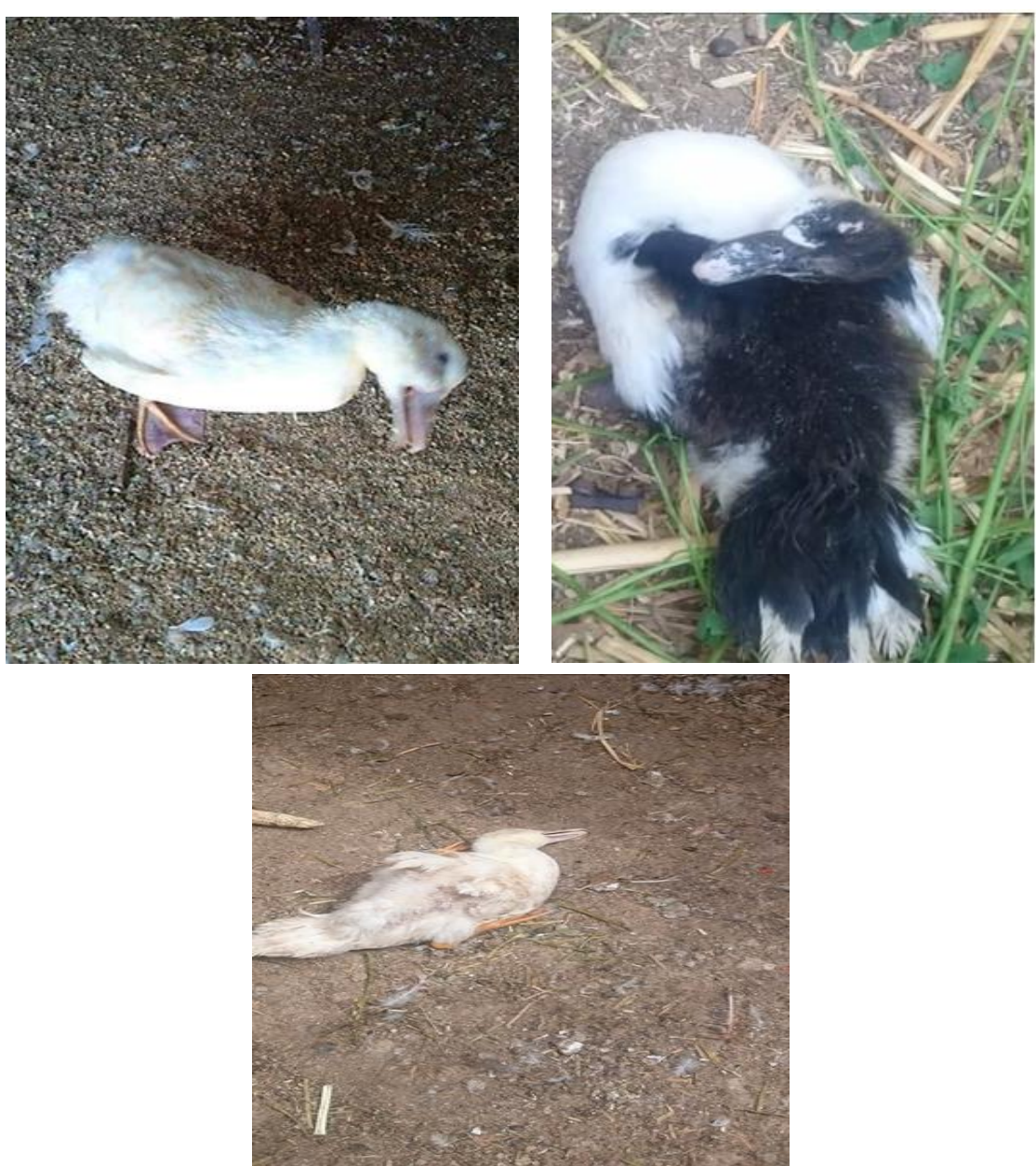

Fig. (2): PCR profile showing positive and negative H5 samples (Positive samples have different crossing points but negative samples have no crossing points). 


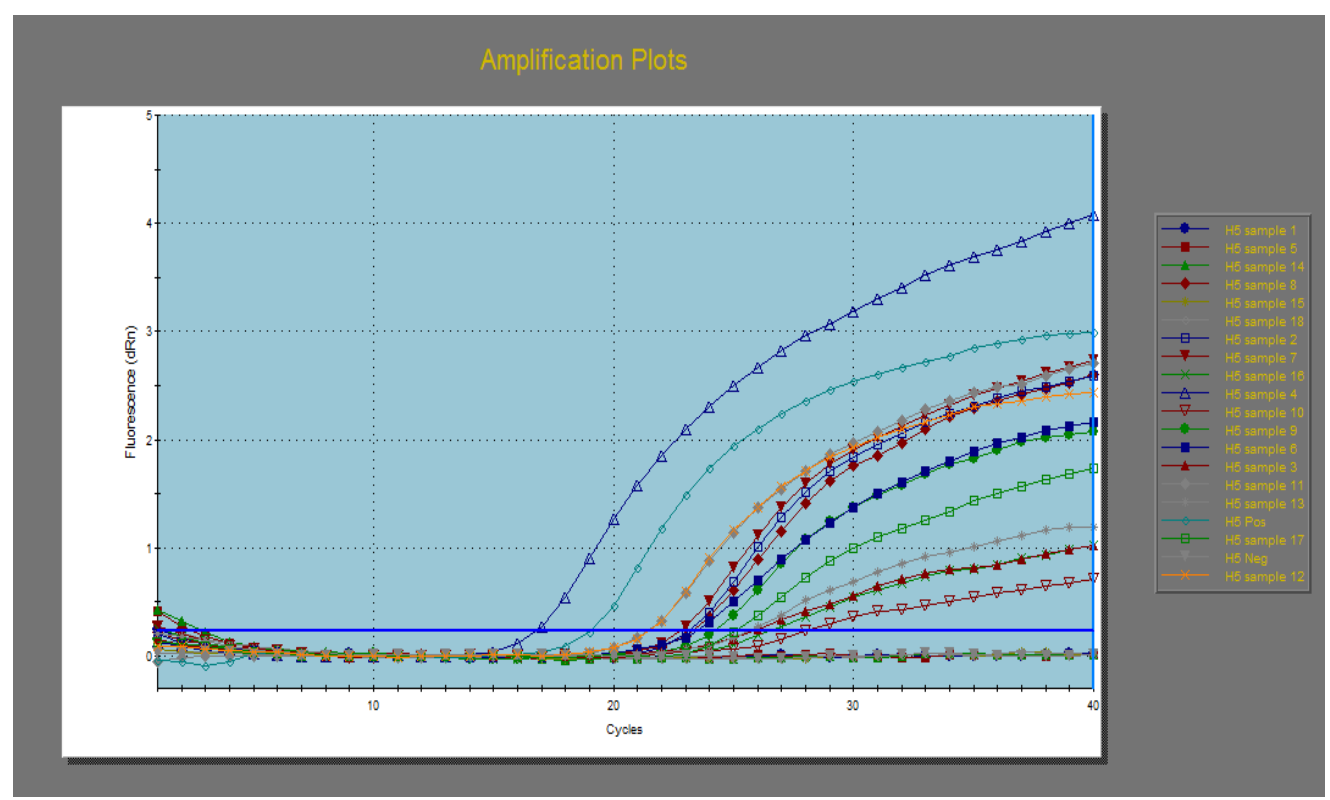

Fig. (3): RT-PCR profile showing positive N8 samples which have different crossing points as well as positive control.

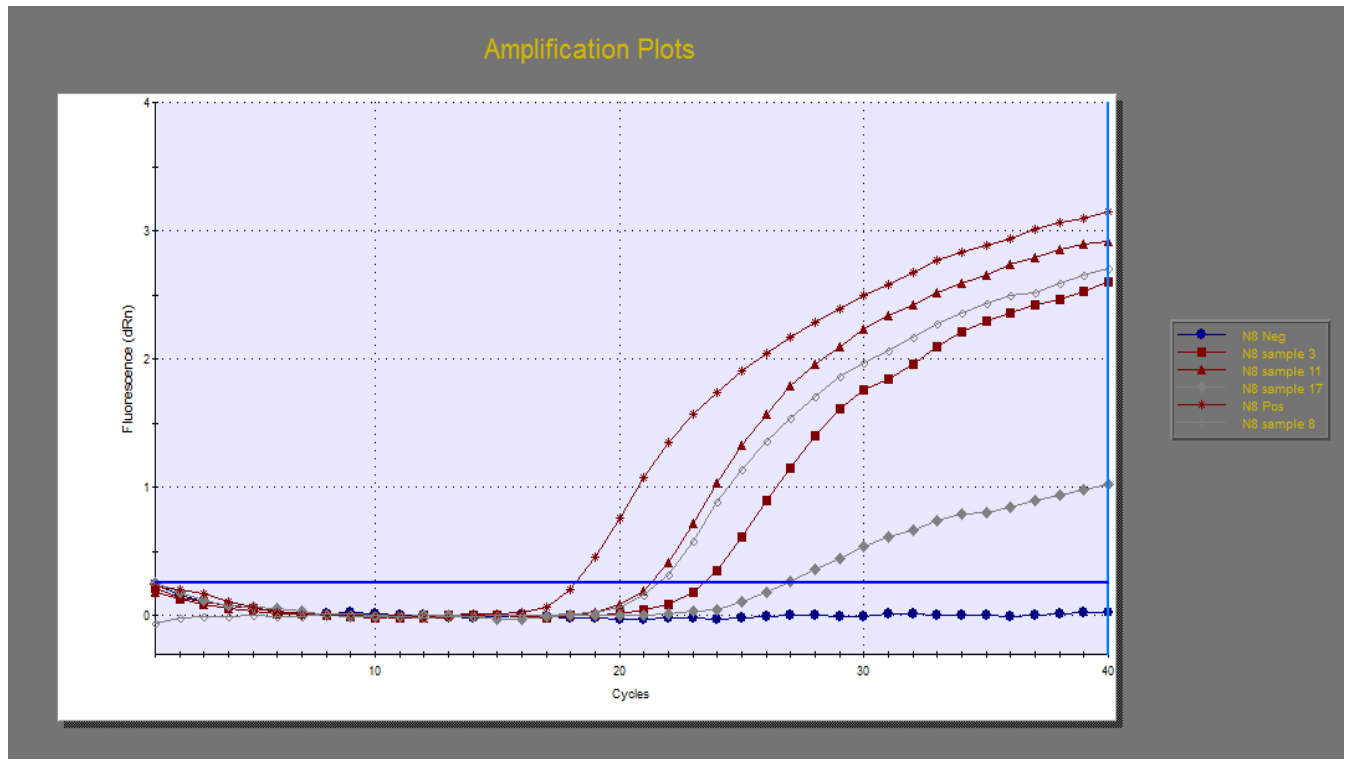

\section{DISCUSSION}

Detection of the H5N8 virus in Egypt is of concern since it is very likely this will further complicate control of H5N1 HPAI there. H5N1HPAI virus of clade 2.2.1.2 and its earlier relatives have been entrenched in Egypt since the first intercontinental wave in 2005-2006. The H5N8 strain is antigenically distant from vaccine strains currently used to assist in the control of this disease in Egypt's commercial sector and this may result in an increase in outbreaks and accelerated virus spread if it becomes established in poultry. In addition, the presence of two distinct strains will make laboratory detection more complex although options using clade-specific rapid diagnostic tools exist and have been used (Naguib et al., 2017). As of June 2017 multiple cases have been reported in poultry in the
Nile Delta (OIE, 2017e) and some have extended to Upper Egypt, suggesting the virus is likely to become widespread in poultry in this area with a potential spread to other parts of Egypt. Reassortment of genes between the H5N8 virus and the pre-existing $\mathrm{H} 5 \mathrm{~N} 1$ viruses and/or $\mathrm{H} 9 \mathrm{~N} 2$ viruses is possible.

In this study a total 334 cloacal and tracheal swabs were collected from different localities in Aswan Governorate; samples were collected from backyard chicken, duck and geese. These samples were examined for the presence of avian influenza virus (H5, H9 and N1, N8) subtypes by RT-PCR. All positive samples were for $\mathrm{H} 5 \mathrm{~N} 8$ avian influenza virus. HPAI H5N8 virus was detected in domestic ducks and geese in Egypt in 2017 by (Anis et al., 2018) and was detected in 4 poultry flocks not 
vaccinated for H5 in the Nile Delta by (Salaheldin et al., 2018).

The transmission of HPAI H5N8 virus to domestic poultry represents a problem in the control and prevention of AI, particularly in Egypt where HPAI H5N1 and LPAI H9N2 viruses are endemic (Monne et al., 2013). Interestingly, the emergence of novel reassortants of HPAI H5N8 virus through acquiring new genes from the endemic AI viruses is expected and this could be a potential threat to the public health. Therefore, strict control measures should be implemented and followed by all partners in poultry industry in Egypt. Movement control, systematic surveillance for wild and domestic birds, biosecurity measures and vaccination should be applied to minimize the losses from AI epizootic.

H5N8 genome was detected in 26 out of 334 examined birds, giving a ratio of $7.7 \%$. The species wise distribution of RT-PCR results was $8.3 \%$, $7.6 \%, 0.0 \%$ for ducks, chickens and geese respectively. This result was lower than (El-Zoghby et al., 2013) who detect AIV in backyard birds in Egypt and the positive percentage was $10.5 \%$ and this may be due to that the surveillance was performed in 24 provinces (larger area and higher bird population). And higher than (Osman et al., 2015) who detect AI virus (AIV) in Qena and Luxor provinces and positive samples were $(5.64 \%)$ and this may be due to that Aswan is a large province and contain high population of birds.

The highest positive result by rRT-PCR was recorded in ducks. This may reveal that the avian influenza become more endemic in ducks in Egypt, as domestic ducks play an important role in the epidemiology of highly pathogenic $\mathrm{H} 5 \mathrm{~N} 8$ avian influenza. Free-ranging ducks are implicated in the transmission of virus to the environment and subsequently to other ducks or other species, since water in which ducks swim, drink, and eat presents a high exposure risk to humans and other birds. Therefore the risk is greatest in rural areas of affected countries, where domestic ducks and chickens often mingle, frequently sharing the same water supply where the viruses transmitted to chickens under these conditions (Gilbert and Slingenbergh, 2004).

During this study we noticed that the main source of infection was introduction of new birds from market, these new birds transmitted the infection from market to household poultry and this mean that the live bird market has important role in spreading AIV and this comes agree with (Abdelwahab et al., 2010) who said that the LBMs have an important role in the spread of HPAI in Egypt through three main aspects. First, LBMs collect birds from different sources and multiple species of birds as chickens, ducks, geese, turkey, pigeons and rabbits. Second, maintenance of birds all together provides suitable condition for inter- and intra-species transmission. Third, LBMs spread the virus or newly emerged variants to poultry and human in a large extended area.

Highly pathogenic avian influenza (HPAI) H5N8 virus was recently detected in wild birds and domestic poultry in Egypt in the 2016/2017 winter season. Vaccination based on commercial H5 vaccines is used as an essential control strategy in Egyptian poultry. Most of the commercial poultry H5 vaccines used in Egyptian poultry are ineffective because the seed viruses in these vaccines are genetically distinct from the H5N8 viruses currently circulating in Egypt, although some of the commercial vaccines protected chickens from mortality, they failed to prevent chickens from shedding the virus (Kandeil et al., 2018).

\section{CONCLUSION}

The predominance of $\mathrm{H} 5$ infection indicates a need for continuous monitoring of AIV among avian species and the awareness against public health risk. Also, We are in need of updating and reinforcing the H5N8 prevention and control strategies in Egypt. The vaccination strategy should be reconsidered based on currently circulating viruses.

\section{REFERENCES}

Abdelwhab, E.M.; Selim, A.A.; Arafa, A.; Galal, S.; Kilany, W.H.; Hassan, M.K.; Aly, M.M. and Hafez, M.H. (2010): Circulation of avian influenza H5N1 in Live Bird Market in Egypt. Avian Dis; 54: 911-914.

Abdelwhab, E.M.; Grund, C.; Aly, M.M.; Beer, M.; Harder, T.C. and Hafez, H.M. (2011): Multiple dose vaccination with heterologous H5N2 vaccine: immune response and protection against variant clade 2.2.1 highly pathogenic avian influenza $\mathrm{H} 5 \mathrm{~N} 1$ in broiler breeder chickens. Vaccine, 29, 6219-6225.

Arafa, A.S.; Hagag, N.; Erfan, A.; Mady, W.; ElHusseiny, M.; Adel, A. and Nasef, S. (2012): Complete genome characterization of avian influenza virus subtype H9N2 from a commercial quail flock in Egypt. Virus Genes, 45, 283-294.

Anis, A.; AboElkhair, M. and Ibrahim, M. (2018): Characterization of Highly Pathogenic Avian Influenza H5N8 Virus from Egyptian Domestic Waterfowl in 2017. Avian Pathol. doi:10.1080/03079457.2018.1470606

Bahl, J.; Pham, T.T.; Hill, N.J.; Hussein, I.T.M.; Ma, E.J. and Easterday, B.C. (2016): Ecosystem interactions underlie the spread of 
avian influenza A viruses with pandemic potential. PLoS Pathogens 12, e1005620.

Ben Shabat, M.; Meir, R.; Haddas, R.; Lapin, E.; Shkoda, I.; Raibstein, I.; Perk, S. and Davidson, I. (2010): Development of a realtime TaqMan RT-PCR assay for the detection of H9N2 avian influenza viruses. J Virol Methods.; 168 (1-2): 72-7.

De Vries, R.D.; De Gruyter, H.L.M.; Bestebroer, T.M.; Pronk, M.; Ron Fouchier, A.M.; Osterhaus, A.D.M.E.; Sutter, G.; Kreijtz, J.H.C.M. and Rimmelzwaan, G.F. (2015): Induction of influenza (H5N8) antibodies by modified vaccinia virus Ankara H5N1 vaccine. Emerging Infectious Diseases, 21, 1086-1088.

El-Zoghby, E.F.; Aly, M.M.; Nasef, S.A.; Hassan, M.K.; Arafa, A.S.; Selim, A.A.; Kholousy, S.G.; Kilany, W.H.; Safwat, $M$. and Abdelwhab, E.M. (2013): Surveillance on A/H5N1 virus in domestic poultry and wild birds in Egypt. Virol. J. 10, 203.

Gilbert, M. and Slingenbergh, J. (2004): Highly pathogenic influenza viruses in Thailand: an analysis of the distribution of outbreaks in the second wave, identification of risk factors and prospects for real-time PCR monitoring. Bangkok: Food and Agriculture Organization of the United Nations and the Department of Livestock Development, Ministry of Agriculture and Cooperatives.

Hoffmann, B.; Hoffmann, D.; Henritzi, D.; Beer, M. and Harder, T.C. (2016): Riems influenza a typing array (RITA): An RT-qPCR-based low density array for subtyping avian and mammalian influenza a viruses. Scientific Reports, 6: 27211, 1-9.

Ibrahim, M.; Eladl, A.F.; Sultan, H.A.; Arafa, A.S.; Abdel Razik, A.G.; Abd El Rahman, S.; ElAzm, K.I.; Saif, Y.M. and Lee, C.W. (2013): Antigenic analysis of $\mathrm{H} 5 \mathrm{~N} 1$ highly pathogenic avian influenza viruses circulating in Egypt (2006-2012). Veterinary Microbiology, 167, 651-661.

Ibrahim, M.; Sultan, H.A.; Abdel Razik, A.G.; Kang, K.; Arafa, A.; Shehata, A.A.; Saif, Y.M. and Lee, C.W. (2015): Development of broadly reactive $\mathrm{H} 5 \mathrm{~N} 1$ vaccine against different circulating H5N1 viruses. Vaccine, 33, 26702677.

Kandeil, A.; Kayed, A.; Moatasim, Y.; Webby, R.J.; McKenzie, P.P.; Kayali, G. and Ali, M.A. (2017): Genetic characterization of highly pathogenic avian influenza A H5N8 viruses isolated from wild birds in Egypt. The Journal of General Virology, 98, 1573-1586.

Kandeil, A.; Sabir, J.; Abdelaal, A.; Mattar, E.H.; El- Taweel, A.N.; Sabir, M.J.; Khalil, A.A.; Webby, R.; Kayali, G. and Ali, M.A. (2018). Efficacy of commercial vaccines against newly emerging avian influenza H5N8 virus in Egypt. Sci Rep, 8: 9697.

Lee, D.H.; Bahl, J.; Torchetti, M.K.; Killian, M.L.; Ip, H.S.; DeLiberto, T.J. and Swayne, D.E. (2016): Highly pathogenic avian influenza viruses and generation of novel reassortants, United States, 2014-2015. Emerging Infectious Diseases, 22, 1283-1285.

Lee, D.H.; Torchetti, M.K.; Winker, K.; Ip, H.S.; Song, C.S. and Swayne, D.E. (2015): Intercontinental spread of Asian-origin H5N8 to North America through Beringia by migratory birds. Journal of Virology, 89, 6521-6524.

Li, L.H.; Yu, Z.; Chen, W.S.; Liu, S.L.; Lu, Y.; Zhang, Y.J.; Chen, E.F. and Lin, J.F. (2013): Evidence for H5 avian influenza infection in Zhejiang province, China, 20102012: a cross-sectional study. J Thorac Dis. 2013 Dec; 5(6): 790-6.

Löndt, B.Z.; Nunez, N.; Banks, J.; Nili, H.; Johnson, L.K. and Alexander, D.J. (2008): Pathogenesis of highly pathogenic avian influenza A/turkey/Turkey/1/2005 H5N1 in Pekin ducks (Anas platyrhynchos) infected experimentally. Avian Pathology (December 2008) 37(6), 619-627.

Monne, I.; Hussein, H.A.; Fusaro, A.; Valastro, V.; Hamoud, M.M.; Khalefa, R.A.; Dardir, S.N.; Radwan, M.I.; Capua, I. and Cattoli, G. (2013): H9n2 influenza A virus circulates in H5N1 endemically infected poultry population in Egypt. Influenza and Other Respiratory Viruses, 7, 240-243.

Naguib, M.M.; Graaf, A.; Fortin, A.; Luttermann, C.; Wernery, U.; Amarin, N.; Hussein, H.A.; Sultan, H.; Al Adhadh, B.; Hassan, M.K.; Beer, M.; Monne, I. and Harder, T.C. (2017): Novel real-time PCR based patho- and phylotyping of potentially zoonotic avian influenza A subtype H5 viruses at risk of incursion into Europe in 2017. Euro. Surveill., 22(1). pii: 30435. doi: 10.2807/1560-7917.ES.2017.22.1.30435.

http://www.eurosurveillance.org/ViewArticle .aspx? ArticleId $=22681$

OIE. (2017e): Follow Up Report 3. Highly pathogenic influenza A viruses (terrestrial poultry), Egypt. http://www.oie.int/ wahis_2/public/wahid.php/Review report/Review?reportid=23232

Olsen, B.; Munster, V.J.; Wallensten, A.; Waldenstrom, J.; Osterhaus, A.D. and Fouchier, R.A. (2006): Global patterns of influenza a virus in wild birds. Science, 312, 384-388.

Osman, N.; Sultan, S.; Ahmed, AI.; Ibrahim, RS.; Abd EL-Wanes, SA. and Ibrahim, EM. (2015): Molecular epidemiology of avian influenza virus and incidence of $\mathrm{H} 5$ and $\mathrm{H} 9$ 
virus subtypes among poultry in Egypt in 2009-2011. Acta virologica 59: 27 - 32.

Park, S.J.; Si, Y.J.; Kim, J.; Song, M.S.; Kim, S.M.; Kim, E.H.; Kwon, H.; Kim, Y.I.; Lee, O.J.; Shin, O.S.; Kim, C.J.; Shin, E.C. and Choi, Y.K. (2016): Cross-protective efficacies of highly-pathogenic avian influenza H5N1 vaccines against a recent $\mathrm{H} 5 \mathrm{~N} 8$ virus. Virology, 498, 36-43.

Saad, M.D.; Ahmed, L.S.; Gamal-Eldein, M.A.; Fouda, M.K.; Khalil, F.; Yingst, S.L.; Parker, M.A. and Montevillel, M.R. (2007): Possible avian influenza (H5N1) from migratory bird, Egypt. Emerging Infectious Diseases, 13, 1120-1121.

Salaheldin, AH.; El-Hamid, HS.; Elbestawy, AR.; Veits, J.; Hafez, HM.; Mettenleiter, TC. and Abdelwhab, EM. (2018): Multiple Introductions of Influenza $\mathrm{A}(\mathrm{H} 5 \mathrm{~N} 8)$ Virus into Poultry, Egypt, 2017. Emerg Infect Dis 2018 May; 24(5). doi: 10.3201/eid2405.

Selim, A.A.; Erfan, A.M.; Hagag, N.; Zanaty, A.; Samir, A.H.; Samy, M.; Abdelhalim, A.;
Arafa, A.A.; Soliman, M.A.; Shaheen, M.; Ibraheem, E.M.; Mahrous, I.; Hassan, M.K. and Naguib, M.M. (2017): Highly pathogenic avian influenza virus (H5N8) clade 2.3.4.4 infection in migratory birds, Egypt. Emerging Infectious Diseases, 23, 1048-1051.

Webster, R.G.; Bean, W.J.; Gorman, O.T.; Chambers, T.M. and Kawaoka, Y. (1992): Evolution and ecology of influenza A viruses. Microbiological Reviews, 56, 152-179.

World Organisation for Animal Health [OIE]. (2018): OIE situation report for avian influenza (latest update: 28 February 2018). Paris: Author.

Yehia, N.; Naguiba, M.M.; Li, R.; Hagag, N.; ElHusseiny, M.; Mosaad, Z.; Nour, A.; Rabea, N.; Hasan, W.M.; Hassana, M.K.; Harder, T. and Arafa, A.A. (2018): Multiple introductions of reassorted highly pathogenic avian influenza viruses (H5N8) clade 2.3.4.4b causing outbreaks in wild birds and poultry in Egypt. Infection, Genetics and Evolution, 58, 56-65.

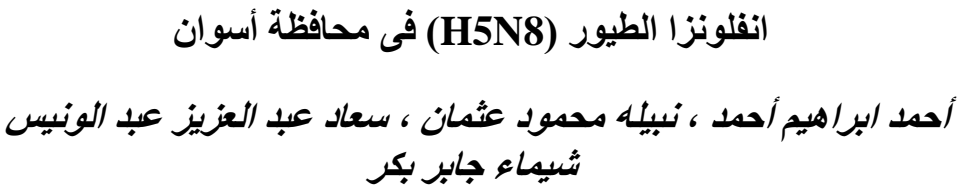

E-mail: Ibrahim.ahmed25@yahoo.com Assiut University web-site: www.aun.edu.eg

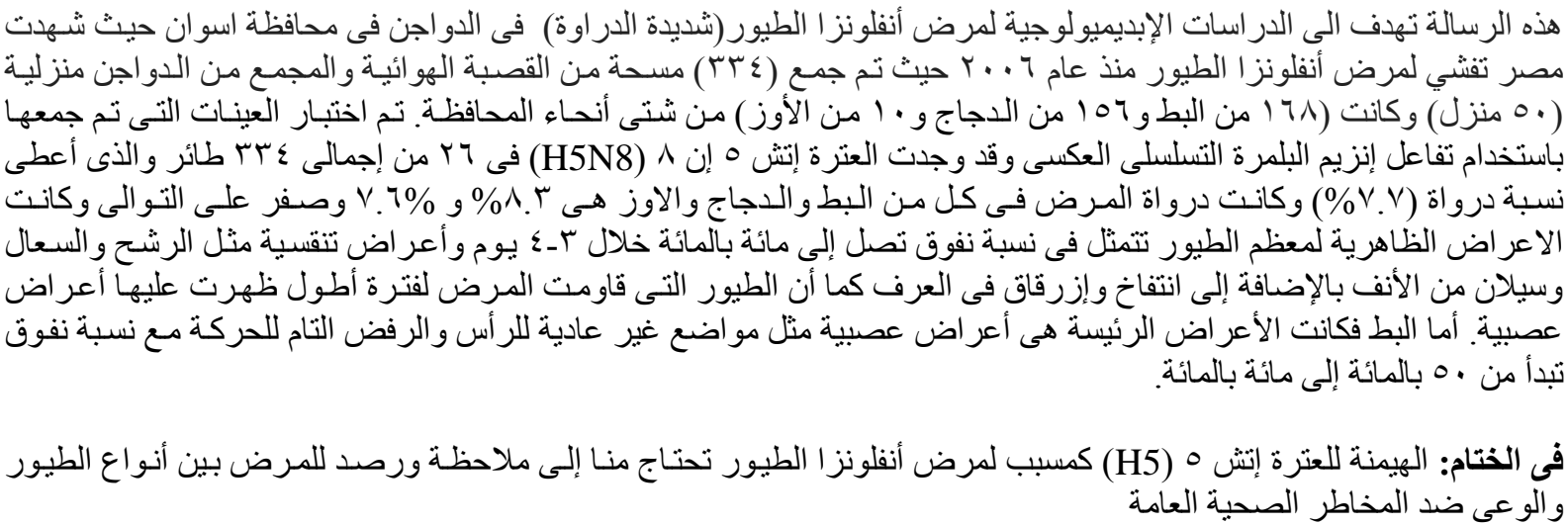

